\title{
ANALISIS STRUKTUR INDUSTRI PEMBIAYAAN INDONESIA
}

\author{
Suwinto Johan \\ STIE Wiyata Mandala \\ suwintojohan@gmail.com
}

\begin{abstract}
The aim of this paper is to study the structure of the Indonesia Finance Company Industry over the periode 20012010. The finance company industry is growing rapidly from Rp37 trillion in 2001 to Rp221 trillion in 2010 with a compounded annual growth rate (CAGR) of $122 \%$. At the same time, the number company in the industry has reduced from 245 in 2001 to 191 in 2010. We use the Concentration Ratio to measure the structure of the industry. Our sample consists of 97 companies in 2001 to 127 companies to 2010. The empirical results show that Indonesia finance company industry is not highly concentrated. In fact, there is a significant increase in the concentration ratio since 2000 to 2010, especially the concentration in Concentration Ratio of 4 largest companies (CR4), Concentration Ratio of 8 largest companies (CR8) and Concentration Ratio of 12 largest companies (CR12). However, there is a potential of higher concentration if we group the companies by the shareholders' ownership, due to the controlling issue of the shareholders.
\end{abstract}

Keywords : Market Structure, Concentration Ratio, Regulation

JEL Classification Code : D4, G21, K21, L11, L22

\section{PENDAHULUAN}

Industri pembiayaan hadir seiring dengan perkembangan otomotif di Indonesia sekitar tahun 1974. Surat keputusan bersama (SKB) tiga menteri, yaitu Menteri Keuangan, Menteri Perindustrian, dan Menteri Perdagangan, yang menjadi landasan kehadiran industri pembiayaan. Perusahaan pembiayaan pertama yang berdiri adalah PT Pembangunan Armada Niaga Nasional (PANN) pada 1975. Perusahaan pembiayaan swasta pertama lahir pada 21 April 1975 yakni PT. Orient Bina Usaha Leasing yang dimiliki oleh Yayasan Kesejahteraan Karyawan Bank Indonesia (YKKBI) dan Orix Jepang.

Ijin perusahaan pembiayaan diperluas oleh pemerintah melalui Keputusan Presiden (Keppres) No.61/1988, yang ditindaklanjuti dengan SK Menteri Keuangan No. 1251/KMK.013/1988. Ijin usaha mencakup sewa guna usaha (leasing), anjak piutang (factoring), pembiayaan konsumen (consumer finance), modal ventura dan kartu kredit.

Perusahaan pembiayaan mengalami pasang surut seiring dengan perekonomian nasional. Jenis barang yang dibiayai oleh perusahaan pembiayaan semakin luas dari waktu ke waktu. Perusahaan pembiayaan fokus pada pembiayaan transportasi seperti kendaraan roda 4 dan roda 2 pada tahap awal. Pembiayaan telah berkembang pada peralatan manufaktur, konstruksi, pertambangan, pertanian, perkantoran, peralatan medis dan perkapalan.

Perusahaan pembiayaan memiliki pada sumber pendanaan selama 40 tahun terakhir. Pendanaan perusahaan pembiayaan menghadapi dampak yang besar dengan diterbitkannya SE BI 28/11/UUPB tahun 1996. Bank Indonesia mengeluarkan peraturan yang melarang investasi pada promes yang diterbitkan oleh perusahaan pembiayaan oleh perbankan. Perusahaan pembiayaan memiliki ketergantungan pendanaan hampir $100 \%$ pada industri perbankan pada saat itu. Pendanaan hanya bisa diperoleh dari 2 sumber yakni perbankan dan ekuitas dari pemegang saham. Ketergantungan dana menentukan kemampuan bersaing perusahaan pembiayaan. 
Pemerintah telah memperbolehkan perusahaan pembiayaan menerbitkan surat utang sejak tahun 2006. Surat utang ini wajib diperingkat oleh perusahaan pemeringkat yang diakui oleh otoritas. Jumlah minimun penerbitan sebesar Rp. 1 Milliar. Pembatasan nilai ini membatasi investor retail yang bisa ikut memberikan pendanaan kepada perusahaan pembiayaan.

Industri pembiayaan juga tergantung pada industri manufaktur yang menjual produknya melalui pembiayaan. Industri pembiayaan merupakan industri yang permintaannya turunan (derived demand) (Hutabarat, 2012). Pembiayaan hanya bisa dilakukan jika terdapat produk atau jasa yang ditransaksikan (underlying product or service).

Industri pembiayaan di bawah naungan Peraturan Presiden No. 9 tahun 2009 sebagai payung tertinggi hukum di Indonesia. Industri pembiayaan belum memiliki Undang Undang hingga saat ini. Industri pembiayaan memberikan kontribusi sebesar 3,59\% terhadap gross domestic product (Nuryartono 2012). Industri pembiayaan memberikan kontribusi sebesar $12,5 \%$ terhadap total penyaluran kredit Indonesi pada tahun 2011.

Penelitian ini menfokuskan pada pengukuran rasio konsentrasi (concentration ratio) dan Herfindahl Index industri pembiayaan di Indonesia dari tahun 2000 - 2011. Selama periode ini, merger dan akuisisi yang terjadi pada ndustry pembiayaan mencapai 30 transaksi. Penelitian ini juga akan didukung dengan pengukuran profitabilitas, market conduct dan kemungkinan kolusi antar pelaku industri. Penelitian ini menarik disebabkan karena meneliti perkembangan konsentrasi sebuah industri di Indonesia selama 11 tahun ke belakang dan potensi-potensi perkembangannya di masa yang akan datang.

Selanjutnya, penelitian akan dilanjutkan dengan penelitian-penelitian sebelumnya pada bagian kedua, diteruskan dengan penjelasan mengenai data dan metodologi pada bagian ketiga, kemudian akan diikuti dengan diskusi dan analisis di bagian keempat. Bagian kelima akan memberikan kesimpulan.

\section{PENELITIAN-PENELITIAN SEBELUMNYA}

Pendekatan structure-conduct-performance diformulasikan oleh Edward S. Mason (1949) bersama rekannya Joe S. Bain (1956). Structure-conduct-performance merupakan sebuah metode dalam menganalisa organisasi industri. Organisasi industri merupakan bagian daripada ilmu ekonomi yang menjelaskan bagaimana sebuah pasar atau industri dibentuk oleh organisasi tertentu dan bagaimana organisasi ini mempengaruhi kinerja pasar. Mason dan Bain menegaskan bahwa adanya hubungan langsung dan kuat antara struktur industri (market structure), aktivitas bisnis dan perilaku pasar (market conduct) dan kinerja industri ini sendiri (market performance). (Muslim, 2008)

Pendekatan lainnya adalah pendekatan non struktural. Kondisi kompetitif seperti harga yang efisien dapat dicapai dalam kondisi pasar yang tidak konsentrasi maupun yang terkonsentrasi sehingga hubungan antara struktur pasar dan kinerja adalah tidak linear. Pandangan ini menyarankan untuk lebih fokus pada competitive conduct daripada struktur pasar. (Bikker dan Haaf, 2001)

Mulyaningsih dan Daly (2011) meneliti terhadap industri perbankan Indonesia dari tahun 20012009. Hasil penelitiannya mendukung pemikiran konvensional, bahwa pasar yang konsentrasi mengakibatkan kompetisi yang tidak seimbang. Pasar yang paling kompetitif adalah pasar perbankan kelas menengah karena konsentrasi yang rendah. Sebaliknya perbankan besar lebih konsentrasi mengakibatkan menurunnya tingkat kompetisi. Kebijakan konsolidasi oleh bank 
sentral mengurangi tingkat konsentrasi. Kebijakan konsolidasi terjadi pada bank ukuran menengah dan kecil. Peningkatan distribusi pangsa pasar dan kapasitas daripada bank hasil merger akan meningkatkan kompetisi di industri perbankan Indonesia.

Alfarisi (2009) menemukan bahwa kinerja industri pulp dan kertas Indonesia merupakan fungsi dari elemen-elemen pembentuk stuktur pasar yaitu tingkat hambatan masuk, struktur pasar, pertumbuhan output dan tingkat efisiensi. Hasil penelitian ini mendukung pemikiran konvensional. Penelitian ini dilakukan pada indsutri pulp and paper untuk periode waktu 19932002.

Sebaliknya, Casu dan Girardone (2006) menemukan bahwa tingkat konsentrasi perbankan tidak berhubungan secara langsung dengan tingkat kompetisi. Penelitian ini juga tidak menemukan bukti bahwa sistem perbankan yang efisiensi tinggi, akan lebih kompetitif. Peneltian ini dilakukan pada European Union dari periode 1997-2003.

Bikker dan Haaf (2001) meneliti terhadap 23 industri perbankan pada 23 negara. Penelitian ini mengindikasikan terjadi kompetisi monopolistik. Persaingan menunjukkan tingkat yang rendah pada pasar domestik dan lebih tinggi pada pasar internasional. Penelitian ini menemukan bahwa konsentrasi akan mengakibatkan kompetisi yang tidak seimbang.

Berger dan Humprey (1993) meneliti fungsi biaya dan keuntungan pada industri perbankan di Amerika Serikat. Penelitian ini menemukan bahwa pasar yang konsentrasi akan memberikan harga yang kurang menguntungkan untuk nasabah, akan tetapi memiliki efek yang kecil pada keuntungan.

Al-Muharrami (2008) meneliti industri perbankan di 6 negara teluk dari tahun 1993 - 2002 dengan mempergunakan Hierfindahl-Hirschman Index dan K Bank Concentration Ratio. Penelitian ini menemukan tidak terdapatnya konsentrasi perbankan di negara-negara teluk. Empat negara mengalami penurusan rasio konsentrasi di industri perbankan dan dua negara memiliki rasio konsentrasi di industri perbankan yang stabil.

Dari 73 penelitian mengenai structure-conduct-performance perbankan di Amerika Serikat sejak tahun 1961 hingga 1991, disimpulkan bahwa pengukuran yang paling umum dipergunakan adalah rasio konsentrasi deposito dari 3 perusahaan terbesar. Pengukuran ini dipergunakan pada 37 penelitian daripada 73 penelitian. Pengukuran kedua yang paling lazim dipergunakan adalah Herfindahl index, diikuti selanjutnya jumlah perusahaan yang ada pada industri. (Molyneux et al. (1996) dalam Al-Muharrami (2008)).

\section{METODE PENELITIAN}

\section{Concentration Ratio (CR)}

Rasio Konsentrasi merupakan akumulasi pangsa pasar yang diperoleh oleh jumlah $\mathrm{N}$ perusahaan yang memiliki pangsa pasar terbesar di ndustry. Formula sebagai berikut :

$$
\begin{aligned}
& \boldsymbol{C R} \mathrm{n}=M S_{1}+M S_{2}+M S_{3}+\cdots+M S_{i} \\
\boldsymbol{C R} \mathrm{n}= & \sum_{k=1}^{n} M S i
\end{aligned}
$$

Keterangan : MS : Market Share

i : perusahaan ke-i 


\section{Karakter Pasar}

Karakter pasar bisa diidentifikasikan termasuk kategori monopoli, oligopoli, atau persaingan sempurna. Sebuah pasar dikategorikan sebagai monopoli jika CR4 (rasio konsentrasi untuk 4 pemain terbesar) lebih dari pada 70\%. Sedangkan sebuah pasar dikategorikan sebagai oligopoli jika CR4 berada pada 40\% hingga 70\%. (Muslim, 2008).

\section{Data}

Penelitian ini menggunakan data sekunder yang dikumpulkan dari berbagai instansi dan literatur resmi, yakni data keuangan publikasi masing-masing perusahaan pada berbagai media massa, laporan tahunan untuk perusahaan yang telah terbuka, laporan penelitian dari berbagai sekuritas, laporan penelitian dari majalah-majalah dan data base di Bloomberg khususnya mengenai transaksi merger dan akuisisi.

Objek penelitian adalah seluruh perusahaan pembiayaan di Indonesia pada tahun 2001 hingga 2011 yang menerbitkan laporan keuangan. Jumlah perusahaan tercatat di Bapepam LK adalah sebanyak 191 perusahaan. Kriteria pengambilan sampel :

1. Perusahaan pembiayaan yang tercatat di Badan Pengawas Pasar Modal dan Lembaga Keuangan (Bapepam-LK) pada tahun 2011.

2. Perusahaan pembiayaan yang aktif menerbitkan laporan keuangan pada periode 2001 2011.

3. Perusahaan pembiayaan yang mengumumkan aksi korporasi akuisisi selama periode 2001 - 2011 di berbagai media massa atau laporan tahunan.

Sampling unit adalah perusahaan pembiayaan. Sampling frame adalah daftar nama perusahaan yang tercatat di Bapepam LK dan menerbitkan laporan keuangan selama periode 2001-2011. Sampling size adalah jumlah seluruh perusahaan pembiayaan yang tercatat di Bapepam LK dan memenuhi kriteria yang ditetapkan.Penelitian ini mempergunakan purposive sampling dengan judgement sampling.

\section{HASIL DAN PEMBAHASAN}

Pengukuran Concentration Ratio dengan mempergunakan total aset yang dimiliki oleh perusahaan pembiayaan disajikan pada Tabel 1 . Tabel 1 menunjukkan peningkatan concentration ratio 4 (CR4) sebesar 6,5\% dari 22,95\% pada tahun 2000 menjadi $29,45 \%$ pada tahun 2010. Concentration Ratio 8 (CR8) meningkat sangat signifikan sebesar $14,64 \%$ dari $35,86 \%$ pada tahun 2000 menjadi 50,05\% pada tahun 2010. Peningkatan $41 \%$ dibandingkan pada tahun 2000. Concentration Ratio 12 (CR 12) meningkat sebesar 9,25\% dari 48,69\% di tahun 2000 menjadi 57,94\% di tahun 2010. Sedangkan CR20 tidak menunjukkan peningkatan yang signifikan. Peningkatan ini menunjukkan semakin terkonsentrasinya industri perusahaan pembiayaan di Indonesia. Hal ini akan memperlukan perhatian daripada pihak terkait terutama regulator dalam mengatur persaingan usaha terutama jika ada transaksi merger dan akuisisi yang akan terjadi.

Pada table 1 menunjukkan HH Index meningkat dari 313 menjadi 383. Pada tahun 2006 mencapai HH Index tertinggi yakn sebesar 443 pada tahun 2006. Peningkatan konsentrasi ini diiringi dengan menurunnnya jumlah perusahaan sebanyak 54 perusahaan dari 245 perusahaan 
menjadi 191 perusahaan. HH Index sebesar 383 menunjukkan bahwa industri perusahaan pembiayaan Indonesia memiliki tingkat konsentrasi yang rendah. Dengan HHI termasuk kategori rendah, maka masih memungkinkan terjadi transaski merger dan akuisi dan industri pembiayaan. Sedangkan Concentration Ratio 4 (CR4) sebesar 29,45\%, tidak menunjukkan industri pembiayaan Indonesia termasuk pada kateogri monopoli maupun oligopoli.

Tabel 1 : Concentration Ratio (CR) dan HH Index Industri Pembiayaan Indonesia Tahun 2000 2010

\begin{tabular}{llllll}
\hline Tahun & CR4 & CR8 & CR12 & CR20 & $\begin{array}{l}\text { Jumlah } \\
\text { Perusahaan }\end{array}$ \\
\hline 2000 & $22.95 \%$ & $35.86 \%$ & $48.69 \%$ & $68.46 \%$ & 245 \\
2001 & $29.24 \%$ & $41.80 \%$ & $51.87 \%$ & $71.43 \%$ & 245 \\
2002 & $25.75 \%$ & $43.59 \%$ & $54.33 \%$ & $70.22 \%$ & 244 \\
2003 & $29.43 \%$ & $45.29 \%$ & $57.15 \%$ & $72.79 \%$ & 239 \\
2004 & $31.24 \%$ & $48.97 \%$ & $58.32 \%$ & $72.40 \%$ & 237 \\
2005 & $27.71 \%$ & $47.24 \%$ & $56.59 \%$ & $71.48 \%$ & 236 \\
2006 & $30.23 \%$ & $49.27 \%$ & $60.46 \%$ & $73.58 \%$ & 214 \\
2007 & $27.90 \%$ & $44.75 \%$ & $55.31 \%$ & $69.77 \%$ & 217 \\
2008 & $26.24 \%$ & $42.30 \%$ & $52.68 \%$ & $69.31 \%$ & 212 \\
2009 & $28.77 \%$ & $46.53 \%$ & $55.37 \%$ & $69.41 \%$ & 203 \\
2010 & $29.45 \%$ & $50.05 \%$ & $57.94 \%$ & $71.30 \%$ & 191 \\
\hline
\end{tabular}

Sumber : Laporan Keuangan Perusahaan Pembiayaan

Perhitungan index dan rasio di atas belum memasukkan faktor kepemilikan pada masing-masing perusahaan pembiayaan. Beberapa perusahaan pembiayaan dimiliki oleh satu pemegang saham utama yang sama. Pengaturan kepemilikan tunggal (Single Presence Policy) telah diberlakukan pada industri perbankan, akan tetapi belum diberlakukan pada industri pembiayaan. Penggelompokkan perusahaan pembiayaan didasari pada potensi pengaturan pasar oleh pemegang saham yang sama terhadap perusahaan pembiayaan yang dimilikinya. Dengan pengaturan ini, maka potensi terjadi trust atau pengaturan harga akan terjadi. Penggelompokkan kepemilikan tersebut bisa dilihat pada tabel 2 dibawah ini.

Dengan memperhitungkan kepemilikan saham pada perusahaan pembiayaan berdasarkan grupgrup perusahaan, maka diperoleh HHI yang meningkat dari 383 menjadi 1034 pada tahun 2010 . HHI ini masih dikategorikan industri pembiayaan sebagai industri yang memiliki konsentrasi moderat.

Tabel 3 menunjukkan Concentration Ratio memiliki pola yang dengan HHI. CR4 meningkat 29,45\% perusahaan individual di tabel 1 menjadi 53,60\% pada kelompok grup perusahaan di tahun 2010 di tabel 3. Empat grup perusahaan terbesar pada industri ini menguasai 53,60\% dari total pembiayaan. Delapan grup perusahaan pembiayaan menguasai sebesar $65,28 \%$ dari total nilai pembiayaan. Dua belas grup perusahaan pembiayaan menguasai $73,45 \%$ total nilai pembiayaan. Dua puluh grup perusahaan pembiayaan menguasai $84,51 \%$ total nilai pembiayaan.

Concentration Ratio ini meningkat selama 11 tahun terakhir. Peningkatan terbesar pada CR4 mencapai $11,57 \%$ dari $42,03 \%$ pada tahun 2000 menjadi 53,60\% pada tahun 2010. Peningkatan terbesar kedua terjadi pada CR8 dari 57,03\% menjadi $65,28 \%$. Peningkatan perlu menjadi 
perhatian regulator terutama Komisi Pemantau Persaingan Usaha (KPPU) terhadap potensi kartel terutama menyangkut harga dan pasar yang dimasukki.

Tabel 2 : Kelompok Perusahaan Pembiayaan di Indonesia

\begin{tabular}{l|l}
\hline Group Perusahaan & Perusahaan Pembiayaan Yang Memiliki Hubungan Affiliasi \\
\hline Astra Grup & $\begin{array}{l}\text { Astra Sedaya Finance, Federal International Finance, Komats Astra Finance, } \\
\text { Surya Artha Nusantara Finance, Toyota Astra Finance, Astra Multi Finance, } \\
\text { Astra Auto Finance, Swadharma Estika Sedaya Finance, Staco Estika Sedaya } \\
\text { Finance, Pratama Sedaya Finance }\end{array}$ \\
\hline Sumitomo Grup & Oto Multiartha, Summit Oto, Sumitomo Mitsui Financial Lease \\
\hline CIMB Niaga Grup & CIMB Niaga Auto Finance / Saseka Gelora, KITA Finance \\
\hline CT Corp & Mega Finance, Mega Auto Finance, Mega Central Finance \\
\hline Mitsui Grup & Bussan Auto Finance, Mitsui Finance \\
\hline Mitsubishi Grup & Indomobil Finance, Swadharma Indotama Finance, Bringin Indotama Finance \\
\hline BTMUFJ Grup & Tigaberlian Auto Finance, Dipo Finance, Bringin Srikandi Finance \\
\hline Panin Grup & U Finance, BTMU BRI Finance \\
\hline
\end{tabular}

Sumber : dari berbagai sumber

Tabel 3 : Concentration Ratio dan HH Index Industri Pembiayaan Indonesia Tahun 2000 - 2010 (Berdasarkan Penggelompokkan Kepemilikan Perusahaan)

\begin{tabular}{llllll}
\hline Tahun & CR4 & CR8 & CR12 & CR20 & $\begin{array}{l}\text { Jumlah } \\
\text { Perusahaan }\end{array}$ \\
\hline 2000 & $42.03 \%$ & $57.30 \%$ & $68.58 \%$ & $82.25 \%$ & 245 \\
2001 & $43.12 \%$ & $59.17 \%$ & $69.95 \%$ & $82.90 \%$ & 245 \\
2002 & $39.60 \%$ & $59.85 \%$ & $69.69 \%$ & $82.00 \%$ & 244 \\
2003 & $43.03 \%$ & $60.27 \%$ & $72.26 \%$ & $83.96 \%$ & 239 \\
2004 & $44.25 \%$ & $65.97 \%$ & $75.33 \%$ & $86.23 \%$ & 237 \\
2005 & $42.19 \%$ & $65.18 \%$ & $74.96 \%$ & $85.42 \%$ & 236 \\
2006 & $48.04 \%$ & $66.91 \%$ & $77.57 \%$ & $87.17 \%$ & 214 \\
2007 & $44.57 \%$ & $61.14 \%$ & $72.70 \%$ & $85.59 \%$ & 217 \\
2008 & $47.65 \%$ & $62.87 \%$ & $73.97 \%$ & $85.38 \%$ & 212 \\
2009 & $52.02 \%$ & $65.58 \%$ & $74.39 \%$ & $84.80 \%$ & 203 \\
2010 & $53.60 \%$ & $65.28 \%$ & $73.45 \%$ & $84.51 \%$ & 191 \\
\hline
\end{tabular}

Sumber : Laporan Keuangan Perusahaan Pembiayaan

\section{KESIMPULAN}

Penelitian ini meneliti terhadap structure industri pembiayaan Indonesia dari tahun 2000-2010. Jumlah perusahaan pada industri mengalami penurunan dari 245 buah menjadi 191 buah di tahun 
2010. Selama periode ini, sebanyak 66 ijin perusahaan pembiayaan telah dicabut oleh Menteri Keuangan. Transaksi merger dan akuisisi juga terjadi selama periode ini.

Penelitian ini mempergunakan concentration ratio and Herfindahl-Hirschman Index untuk mengukur struktur industri. Sampel penelitian ini berkisar dari 97 perusahaan pada tahun 2001 hingga 127 perusahaan pada tahun 2010.

Penelitian ini menemukan industri pembiayaan Indonesia ini memiliki tingkat konsentrasi rendah dan dikategorikan sebagai pasar persaingan sempurna. Peningkatan rasio konsentrasi yang signifikan terjadi selama 11 tahun terakhir terutama pada CR4, CR8 and CR12. Akan tetapi, konsentrasi akan meningkat, jika menggabungkan perusahaan-perushaaan pembiayaan yang memiliki pemegang saham yang sama seperti industri perbankan. Penggabungan kepemilikan ini dikenal dengan istilah single presence policy (SPP). Konsentrasi industri pembiayaan juga perlu mempertimbangkan hubungan captive antara perusahaan anak dengan perusahaan induk perbankan maupun otomotif.

\section{DAFTAR PUSTAKA}

AAA Securities, 2009. Research Analyst Report

Al-Muharrami, Saeed, 2008. Measuring the Market Structure of GCC Banking Industries. The Business Review Cambridge Vol. 11 No. 2

Alfarisi, Dicky Ade, 2009. Analisa Struktur dan Kinerja Industry Pulp dan Kertas Indonesia. Journal Persaingan Usaha Komite Pemantau Persaingan Usaha Indonesia

Asosiasi Perusahaan Pembiayaan Indonesia, APPI, 2005-2009. Laporan Tahunan, diunduh dari www.ifsa.or.id

Asosiasi Leasing Asia, ALFA World (AFSA World), 2009 - 2010. Laporan Tahunan, diunduh dari www.alfaworld.org atau www.afsaworld.org.

Bain, Joe S., 1956. Barriers to New Competition. Cambridge, MA: Harvard University Press.

Bapepam LK, 2005 - 2010. Laporan Tahunan, Bapepam, Menteri Keuangan Republik Indonesia

Barbara, Casu dan Girardone, Claudia, 2006. Bank Competition, Concentration And Efficiency In The Single European Market, Manchester School, University of Manchester, vol. 74(4), pages 441-468, 07.

Berger, A.N., dan Humphrey, D., 1993. Bank scale Economies, Mergers, Concentration, and Effciency: the U.S. Experience. Revue d'Economies Financiere 27, 123154.

Berger, Allen N; Demirguc-Kunt, Asli; Levine, Ross; Haubrich, Joseph Gerard, 2004. Bank Concentration and Competition: An Evolution in the Making. Journal of Money, Credit, and Banking, Volume 36, Number 3

Bikker, Jacob A dan Haaf K., 2001. Competition, Concentration and Their Relationship: An Empirical Analysis of the Banking Industry. Section Banking and Supervisory Strategies, Directorate Supervision, De Nederlandsche Bank (DNB)

Johan, Suwinto, 2010. Cross Selling, Majalah Multifinance, Asosiasi Perusahaan Pembiayaan Indonesia

Hutabarat, Mulabasa, 2012. Comparative Study on Regulation and Control Non Bank Financial Institution - Finance Company. Bapepam LK-Mazars-USAID. 
Mason, Edward S., 1939. Price and Production Policies of Large-Scale Enterprise, American Economic Review, 29

Mulyaningsih, Tri Mulyaningsih dan Anne, Daly, 2011. Competitive Conditions in Banking Industry : An empirical Analysis of the Consolidation, Competition and Concentration in the Indonesia Banking Industry between 2001-2009. Faculty of Business and Government, University of Canberra. Buletin Ekonomi, Moneter dan Perbankan, Oktober 2011

Muslim, Erlinda; Evertine Vivi; Nurcahyo Rahmat, 2008. Structure, Conduct and Performance Analysis in Palm Cooking Oil Industy in Indonesia Using Structure Conduct Performance Paradigm (SCP). Proceding International Seminarl on Industrial Enggineering and Management, Santika Hotel, Jakarta. ISSN 1978-774X

Nuryartono, Nunung. 2012. Comparative Study on Regulation and Control Non Bank Financial Institution - Finance Company. Bapepam LK - Mazars, Bidakara Hotel

Pervan, Maja.; Kramarie, Tomislava Pavie.; Pavid Ivan., 2011. Changes of Market Structure and Competition in theCroatian (Non) Life Insurance Industry. The Business Review Cambridge Vol.17 